IJBE (Integrated Journal of Business and Economics)

e-ISSN: 2549-3280/p-ISSN: 2549-5933

\title{
Fixed Sample Size as an Internal Control
}

\author{
Dianita Meirini ${ }^{1}$, Atik Tri Andari ${ }^{2}$, Elmi Rakhma Aalin ${ }^{3}$ \\ ${ }^{1,2,3}$ Polytechnic of Kediri, Indonesia \\ dmeirini@gmail.com
}

\begin{abstract}
This study aims to analyze the effectiveness of internal control on two existing Community Banks in Tulungagung. According to Bank Indonesia rank, Tulungagung occupies the 1st position of the highest NPL in 2016. The effectiveness analysis of internal control is performed on the second Community Bank crediting system that includes qualitative and quantitative aspects analysis. Qualitative aspect analysis is based on Audit Standard applicable in Indonesia (AS) Section 319 Consideration of Internal Control in Audit of Financial Statements paragraph 07. Quantitative aspect analysis using Fixed Sample Size with a 95\% confidence level and fault tolerance / DUPL (Desired Upper Precision Limit) $=5 \%$. The result of the qualitative aspect shows the internal control system in both Community Banks is effective. It's based on conformity between AS Section 319 and its implementation on both Community Bank. Total 20 questions for conformity analysis, 1st Community Bank for the next called BPR A is 80\% appropriate, 2nd Community Bank for the next called BPR B is $60 \%$ appropriate. The rest questions are used as an attribute on quantitative analysis. The result of the quantitative aspect shows the internal control system in both Community Banks is not effective. This is because the AUPL (Achieved Upper Precision Limit) from three attribute samples analyzed exceed specified DUPL, that is: a) Authorization of credit approval documents AUPL $=18 \%, b)$ Completeness of supporting documents attached AUPL $=28 \%$, and c) Verification of transaction correctness and correctness of ceiling calculation AUPL credit $=29 \%$.
\end{abstract}

Article Info

- Received : October 22, 2018

- Revised : December 1, 2018

- Published : January 5, 2019

- No. Pages : 52-64

- DOI : 10.33019/ijbe.v3i1.110

- JEL : E58, G21

- Keywords : internal control, mixed method, fixed sample size

\section{Introduction}

Lending business to the business community by banking institutions is a kind of business that capable of creating generating income. In addition to generating income, the provision of credit also has a risk of Non-Performing Loans (NPL) or bad debt. The higher NPL of a banking company will affect the sustainability of the bank operation. This is convinced by the tempo daily news, which revealed that "Bank Indonesia recorded an increase of NPL ratio in August 2016 to $3.2 \%$ from the previous year of $3.18 \% "$. Therefore, the credit section in a bank must be careful in analyzing credit, so NPL intensity can be minimized. 
NPL intensity can be minimized by the reliability of internal control in the bank's credit system. The good internal control system will greatly assist the entity in avoiding fraud that will harm the customer and the bank (entity) itself. The effectiveness of the internal control system or procedure can result in the reliability of an entity's financial statements. In addition, a sufficient internal control system is basically intended to protect the entity's assets (the bank) by minimizing the possibility of fraud, improvidence, and NPL.

The consideration of effective internal control is built on the basic theory, such as the Agency Theory. Basis theory in this study use agency theory that guides in the implementation and design of an internal control system especially in community bank industries. The importance of internal control effectiveness is to safeguard the interest of stakeholder. This overall theory idea also confirming previous research by (Onumah, Kuipo, \& Obeng, 2012) which also uses the same theory to gives grounds for ascertaining what an effective system of internal control must possess and demonstrate. Increasing in NPL on August 2016 in accordance to Bank Indonesia version indicates that internal control in banking institution's especially credit system is less effective, it cause many loans are not on target. Considering the importance of the internal control effectiveness as a determinant of the entity's operating efficiency, in this study intended to examine the effectiveness of internal control of credit provision at banking institutions, focusing at Community Banks (BPR) in Tulungagung.

According to (Cahyani, 2016) the credit system of Community Bank in Sleman has not fully fulfilled the internal control component according to COSO. Other studies, such as (AkwaaSekyi \& Gené, 2017) provide empirical evidence that internal control in banks has a positive effect on credit risk. Empirical evidence shows that internal control in a bank has an important role in minimizing risk, especially the risk of bad credit (Jayanti Gagola, Ventje Ilat, 2015). Furthermore, the results of (Jayanti Gagola, Ventje Ilat, 2015) provide empirical evidence that internal control at the Bank in North Sulawesi has been effective but still needs to maintain the stability of credit provision based on the prevailing internal control mechanism.

There is a reason for the selection of Community Bank (BPR) Institutions. These reasons are based on a case that occurred in banking institutions in Tulungagung, where banks in Tulungagung have the highest NPL rates among 13 regions in Kediri and Madiun. This information is in accordance with the data compiled from the Financial Services Authority (OJK) NPL data of Kediri. The following table shows data of top 10 NPL in Kediri and Madiun:

Table 1. NPL Ranking of Kediri and Madiun

\begin{tabular}{|c|l|c|}
\hline No & \multicolumn{1}{|c|}{ City } & NPL (\%) \\
\hline 1. & Tulungagung & $3,17 \%$ \\
\hline 2. & Kota Kediri dan Kabupaten & $3,10 \%$ \\
\hline 3. & Ngawi & $3,00 \%$ \\
\hline 4. & Magetan & $2,64 \%$ \\
\hline 5. & Blitar & $2,57 \%$ \\
\hline 6. & Pacitan & $2,20 \%$ \\
\hline 7. & Madiun & $2,18 \%$ \\
\hline 8. & Trenggalek & $1,76 \%$ \\
\hline 9. & Nganjuk & $1,63 \%$ \\
\hline
\end{tabular}




\begin{tabular}{|l|l|c|}
\hline No & City & NPL (\%) \\
\hline 10. & Ponorogo & $1,50 \%$ \\
\hline
\end{tabular}

Source: Financial Services Authority of Indonesia (2016)

Based on the NPL data above, Tulungagung has the highest level of NPL. This means the effectiveness evaluation of internal control in the crediting system of community Banks in Tulungagung need to analyze. This internal control evaluation aims to determine the level of internal control effectiveness of the crediting system at Community Banks in Tulungagung.

We use a sampling attribute to evaluate the internal control system. According to Mulyadi (2009), there are many sampling attributes are as follows Fixed Sample Size Attribute Sampling, Stop-or-Go Sampling, and Discovery Sampling. Fixed Sample Size is a sampling method in testing the internal control effectiveness that is most widely used by auditors. This study will discuss the evaluation of internal control effectiveness of the crediting system using a fixed sample size attribute sampling method.

Considering the importance of the internal control effectiveness of the credit system in banking institutions, in order to reduce the level of Non-Performing Loans (NPL), this study arranges the following questions:

1. Does the internal control of the credit system in Community Banks at Tulungagung corresponding with internal control section of Audit Standard Section 319?

2. Does the internal control of the credit system in Community Banks at Tulungagung effective?

\section{Literature Reviews}

\section{Internal Control System}

IAPI (2011) defines internal control as: "A process obtained by the board of commissioners, management and other personnel of the entity - which is designed to provide reasonable assurance about the achievement of the following three categories of objectives: (a) reliability of financial statements, (b) effectiveness and efficiency of operations, and (c) compliance with applicable laws and regulations. Not too different from those definitions, Mulyadi (2016: 129) also defines the internal control system as a system that includes organizational structure, methods and measures coordinated to maintain organizational assets, check the accuracy and reliability of accounting data encourage efficiency and compliance with management policies. Internal control according to (Beasly, 2012) defines the internal control system as a system designed to provide reasonable certainty regarding the achievement of management objectives regarding financial reporting reliability, effectiveness and efficiency of operations and compliance with applicable laws and regulations. Several definitions related to the internal control system above can be concluded that an internal control system is a process designed to guarantee the achievement of objectives related to the effectiveness and efficiency of operations.

\section{Purpose of the Internal Control System}

According to (Mulyadi, 2015) the main objectives of the internal control system are:

1. Maintain organizational assets

2. Checking the accuracy and reliability of accounting data

3. Drive efficiency 


\section{Encourage compliance with management policies}

\section{Control Testing with Sampling Attribute}

The auditor can take four ways to test characteristic of evidence: 1) take all sample, implement judgment sampling, undertake representative sampling, or perform statistical sampling. If auditors choose judgment sampling, sample selection based on the auditor's judgment and analyzes the results of the sample examination based on the auditor's judgment. Statistical sampling is divided into 1) attributes sampling and 2) variables sampling. Attribute sampling or proportional sampling is used primarily to test the effectiveness of internal control (control testing), while the sampling variable is used primarily to test the rupiah value listed in the account (substantive testing). There are three attribute sampling models: (1) fixed-sample-size attribute sampling, (2) stop or go sampling, (3) discovery sampling.

\section{Fixed Sample Size Attribute Sampling}

This sampling model is the most widely used. Technic sampling with this model is intended to estimate the percentage of certain quality occurrences in a population. For example, with this model, the auditor can estimate the percentage of cash receipts (vouchers) contained in the population without supporting evidence. This model is mainly used if the auditor tests the control of an element of internal control and the auditor estimates there will be encounter several errors (errors). The sampling procedures are as follows:

1. Determination of attributes that will be examined to test the effectiveness of internal control

2. Determination of the population to be sampled

3. Determination of the sample size

4. Selection of sample from the population

5. Examination of attributes that indicate the effectiveness of internal control elements

6. Evaluate the results of the examination of the attributes sample

\section{Control System at Community Bank}

According to (Narotama, Ch; Radianto, 2004) there are two stages of internal control in Community Bank, there are two stages recommendations.

1. Preparation and/ Development of Required Guidelines

The creation and/ development of the necessary guidelines must absolutely be held by several parts that aim to make the part of the task perform quickly, correctly, and accurately. The guidelines must be made and documented as a part of the system guidelines. For example, the accounting department must have an accounting system that is made in accordance with the accounting principles that apply in Indonesia; the credit department must have clear and reliable credit system guidelines, each section must have a documented job description, etc.

2. Internal Control Activities

Internal control activities are activities performed by internal supervisor units with different time dimensions. Some control activities must be implemented in every certain transaction, every day, every month, or every period. After completing control, the internal supervisor unit makes an internal control report.

According to (Narotama, Ch; Radianto, 2004) there are three types of internal control that can be applied, i.e. 1) routine internal control, 2)program internal control, and 3)special internal control. Routine internal control is implemented in each section which includes the credit section, general 
section, general cash fund section, and bookkeeping section. An instance of internal control procedures for credit sections includes dual control, joint custody, mandatory vacation control, number control, limitation outside activities of bank personnel, and rotation of duty assignment control. Examples of bookkeeping internal control procedures include dual control, asset control, mandatory vacation control, number control, independence balancing, and rotation of duty assignment control.

\section{Research Methods}

\section{Type of Research}

The method used in this study is a mixed method. Furthermore, this study uses the exploratory sequential mixed method. According to (J. W. Creswell, 2014) exploratory sequential mixed method is a research procedure which at the initial stage of the research was using qualitative methods and examining more in-depth the views or opinions of participants. The next stage quantitative methods are used to analyze data and information obtained. Thus, this study is divided into two phases. The first phase used interview techniques with exploratory objectives, but with the development of interviews and data obtained, the development of analysis using quantitative methods in the second phase.

\section{Population and Sample}

The population in this study is Community Bank in Tulungagung. Total populations are 15 Community Bank (BPR). The sampling method used in this study is sequential sampling. In accordance with the type of research conduct, i.e. exploratory sequential mixed method. According to (J. Creswell, 2009) sequential sampling method is a sequential sampling method in which the sampling method at the first phase informs the data needed in the second phase sampling method.

The first phase of sampling method in this study uses a non-probability sampling method. This study uses purposive sampling method. According to (Sekaran, 2003) the sampling design with purposive sampling has two types, that is judgment sampling and quota sampling. This study uses judgment sampling. The second phase, the sampling method uses probability sampling. The data analysis process in the second stage was using simple random sampling. Thus, taking a sample from the population is performed randomly without regardless of the strata in the population (Sugiyono, 2017). The data analyzed in the second stage is the total number of credit disbursement transactions at Community Bank that is studied and supplemented with supporting documents, i.e. credit approval documents along with other supporting documents. Data collection techniques used in this study are interviews, questionnaires, and document usage. Data analysis techniques were using the Public Accountant Professional Standards (SPAP) Audit Standard Section 319 concerning Consideration of Internal Control in the Audit of Financial Statements.

\section{Results and Discussions}

\section{General Description of Research Objects}

This research was conducted at Community Bank in Tulungagung area. There are two Community Banks that are used as research focus, hereinafter referred to as BPR A, and BPR B. General description of BPR A and BPR B as follows: 


\section{BPR A}

BPR A is located at Jalan Pahlawan number 4A Tulungagung, East Java. BPR A has a Vision of "Becoming a Trusted Partner of the Community with Excellent Service", while its Mission is as follows: "1) Together with the community to develop the economy with BPR activities and networks, 2) Improve people's welfare through increasing Regional Revenue (PAD), economic activities and sustainable productive business. "BPR A was established based on notarial deed Edy Prayitna, SH. number 7, 21 ${ }^{\text {st }}$ October 2013 and has 32 employees.

\section{BPR B}

BPR B is located at KH Hasyim Asy Ari no. 11A Kauman Tulungagung. The BPR's vision is "To Become a People's Business Partner in National Economic Development", while the BPR's Mission is "Making a Reliable and Healthy Bank". BPR B was established based on notarial deed Yvonne Erawati, SH. Number 4, $4^{\text {th }}$ January 2007. BPR C has 13 permanent employees and 7 non-permanent employees.

\section{Data Analysis and Discussion}

The effectiveness of internal control was tested with two analyzes. The first analysis is an analysis of the elements of internal control in the credit system and second analysis with statistical methods, namely the sampling attribute, in this case, using a fixed sample size to the credit transaction. An element of internal control analysis on the credit system is implemented by internal control elements based on Section 319 audit Standard Consideration of Internal Control in the Financial Report Audit paragraph 07. The elements include: 1) Control Environment; 2) Risk Assessment; 3) Information and communication; 4) Control Activities; 5) Monitoring.

\section{Elemental Analysis of Internal Control on BPR Credit Giving Systems Researched}

Groove analysis is used to analyze the internal control elements in the credit control system of the Community Bank's studied. The explanation of the internal control elements in each Community Bank as follows:

\section{BPR A}

The credit system in BPR A involves three functions, i.e. Account Officer (AO), Credit Administration (Credit Admin), Credit Committee, and Credit Head (Credit Head).

\section{BPR B}

The credit system in BPR A involves three functions, i.e. Account Officer (AO), Accounting, Credit Administration (Credit Admin), Credit Section Head (Credit Head), Directors, Credit Committee, and Teller.

\section{Analysis of Internal Control in BPR A}

This following analysis is an internal control analysis for credit system in BPR A. This analysis is a qualitative aspect. The qualitative analysis here is performed by comparing the internal control of the BPR A credit system with Audit Standard 319 Consideration of Internal Control in the Financial Report Audit paragraph 07. AS 319 includes Control Environment, Risk Assessment, Information and Communication, Control and Monitoring Activities. This comparison aims to analyze the congruence of BPR A internal controls with existing audit standards, especially for credit systems. 
Based on the qualitative analysis, internal control of the credit system at BPR A is effective. This is reflected in the suitability that occurs between elements of AS 319 and their practice in BPR B. Four out of ten sub-points are not appropriate. If calculated by percentage roughly, the internal control of BPR A is $80 \%$ in accordance with AS 319. The discrepancy is $20 \%$ in terms of:

1. There is no Code of Ethics used to regulate the ethics and integrity of all BPR A employees.

2. There is no specific operating style implemented in BPR A.

3. Every function involved and responsible for credit transactions.

4. Correction of document credit calculation is not implemented thoroughly against the existing credit submission documents.

The discrepancy will be continued to be analyzed through quantitative aspect analysis. The main sub-points for conducting quantitative analysis are the correctness of the calculation of existing credit documents, as well as adding other aspects, namely the completeness of documents and authorization of credit documents. The credit documents tested are credit approval documents and supporting documents as samples of the internal control effectiveness test.

\section{Analysis of Internal Control in BPR B}

Based on the qualitative analysis, internal control of the credit system at BPR B can be concluded to be less effective. This is reflected in the congruence that occurs between elements of AS 319 and their practice in BPR B. Not much different with analysis from BPR A, four out of ten sub-points are not appropriate. Roughly if calculated by percentage, the internal control of BPR A is $60 \%$ in accordance with AS 319. The discrepancy is $40 \%$ in terms of:

1. There is no Code of Ethics used to regulate the ethics and integrity of all BPR B employees.

2. There are no specific operating styles implemented in BPR B.

3. Every function involved and responsible for credit transactions.

4. Correction of document credit calculation is not implemented thoroughly against the existing credit submission documents.

The discrepancy will be continued to be analyzed through quantitative aspect analysis. The main sub-points for conducting quantitative analysis are the correctness of the calculation of existing credit documents, as well as adding other aspects, namely the completeness of documents and authorization of credit documents. The credit documents tested are credit approval documents and supporting documents taken as samples of the internal control effectiveness test.

\section{Analysis of Internal Control Effectiveness with Fixed Sample Size at the BPR Researched} Quantitative effectiveness test for the internal control system of credit granting at Community Bank in Tulungagung performed with the sampling attribute model. The sampling attribute model used is a fixed-sample-size sampling attribute. The effectiveness testing of internal control is implemented by estimating the percentage of certain quality occurrences or certain attributes specified in a population. The population referred to the main document and supporting documents in the credit system. The steps in this test are as follows:

1. Determining the sampling attribute for the document being examined, including:

a. Attribute 1: Authorize the credit approval document

b. Attribute 2: Completeness of supporting documents attached 
c. Attribute 3: Verify the correctness of the transaction and credit ceiling calculation

2. Determine the population to be sampled

The population used was credit approval letter and other supporting documents in 2016. This Population used to test the effectiveness of Community Bank in Tulungagung.

3. Determine the size of the sample

The next step is to determine the size of the sample from all existing credit approval letters in 2016 - determination of the number of samples using a fixed sample size sampling method attribute.

4. Choose a sample from all populations randomly.

The sample was chosen randomly to the credit approval document and other supporting documents in 2016. The random collection of credit approval documents and supporting documents was performed three times, the three times taking was based on the number of attributes that had been determined as many as three.

5. Examination of attributes.

If there is a credit approval letter without authorization, incomplete with credit supporting documents, and errors occur in credit ceiling calculation, so that is an attribute. The attribute is a deviation from the elements of internal control that should exist. Based on the random sample obtained there are several deviations or errors found. The following details of the errors found:

a. Attribute 1: Authorize the credit approval document

Deviations that occurred when testing the credit approval document related to the completeness of authorization in the credit approval document and supporting documents during 2016 were 12 documents. In other words, there are 12 credit approval documents that have not been completed with authorization.

b. Attribute 2: Completeness of supporting documents attached

Deviations that occur when testing credit approval documents related to the completeness of supporting documents attached to the credit approval document for 2016 are 48 documents. In other words, there are 48 credit approval documents are not complete with supporting documents.

c. Attribute 3: Verify the correctness of the transaction and the correctness of the credit ceiling calculation

Deviations that occurred when testing credit approval documents related to verifying the truth of the transaction and the correctness of the credit ceiling calculation during 2016 were 60 documents. In other words, there are 60 credit approval documents that are wrong in credit calculation or analysis. The following table 2 is a summary of irregularities or errors found during the examination of samples of credit approval documents and supporting documents. 
Table 2. Examination of Attributes at Community Banks in Tulungagung

\begin{tabular}{|c|l|c|c|c|c|}
\hline No & \multicolumn{1}{|c|}{ Attribute } & Sample & R\% & DUPL & Errors (Attribute) \\
\hline 1 & Credit document authorization & 100 & $95 \%$ & $5 \%$ & 12 \\
\hline 2 & Supporting Document & 200 & $95 \%$ & $5 \%$ & 48 \\
\hline 3 & $\begin{array}{l}\text { Transaction and credit ceiling } \\
\text { calculation verification }\end{array}$ & 240 & $95 \%$ & $5 \%$ & 60 \\
\hline
\end{tabular}

Source: Data processed, 2018

6. Evaluate the results of the examination of sample attributes found in the previous stage. The number of attributes or errors found is used as a determinant of Achieved Upper Precision Limit (AUPL). Results evaluation with a 95\% reliability table for each attribute will be in accordance with the following figures 1,2 and 3.

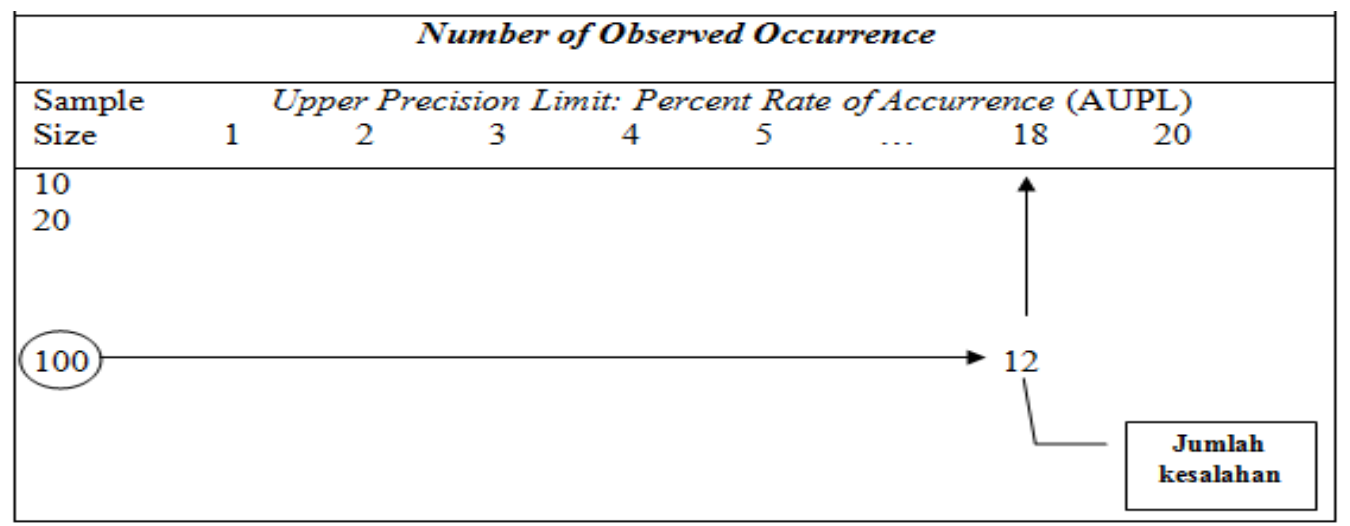

Source: Data processed, 2018

\section{Figure 1. AUPL for $1^{\text {st }}$ Attribute Authorization Credit Document}

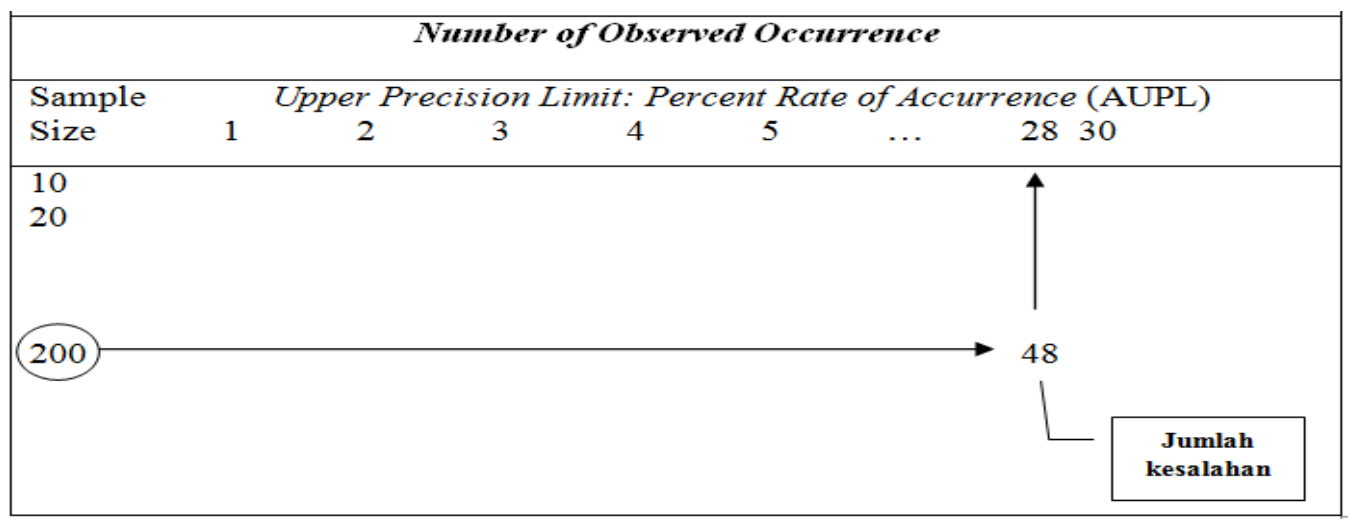

Source: Data processed, 2018

Figure 2. AUPL for $2^{\text {nd }}$ Attributes Supporting Documents 


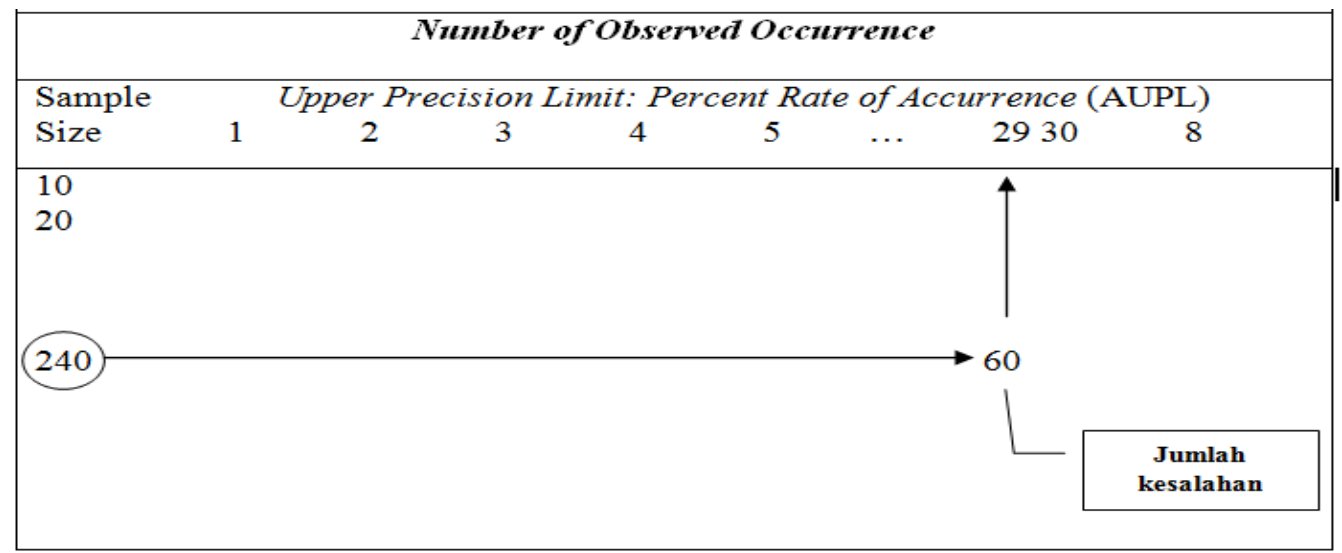

Source: Data processed, 2018

\section{Figure 3. AUPL for $3^{\text {rd }}$ Attributes Transaction and Credit Ceiling Calculation Verification}

In accordance with figure 1, 2, and 3 above, the percentage of irregularities that occur. The rate of deviation is 1) attribute 1 is $18 \%, 2$ ) attribute 2 is $28 \%$, and attribute 3 is $29 \%$. The percentage of irregularities in Achieved Upper Precision Limit (AUPL) is summarized and compared with DUPL in table 3.

Table 3. Internal Control Verification at Community Banks in Tulungagung

\begin{tabular}{|c|c|c|c|c|c|c|c|}
\hline No & Attributes & $\begin{array}{c}\sum \\
\text { Sample }\end{array}$ & $\begin{array}{c}\text { R } \\
(\%)\end{array}$ & DUPL & $\begin{array}{c}\text { Errors } \\
\text { (Attribute) }\end{array}$ & AUPL & $\begin{array}{c}\text { Internal } \\
\text { Control }\end{array}$ \\
\hline 1 & Credit document authorization & 100 & 95 & $5 \%$ & 12 & $18 \%$ & $\begin{array}{c}\text { Not } \\
\text { effective }\end{array}$ \\
\hline 2 & Supporting Document & 200 & 95 & $5 \%$ & 48 & $28 \%$ & $\begin{array}{c}\text { Not } \\
\text { effective }\end{array}$ \\
\hline 3 & $\begin{array}{c}\text { Transaction and credit ceiling } \\
\text { calculation verification }\end{array}$ & 240 & 95 & $5 \%$ & 60 & $29 \%$ & $\begin{array}{c}\text { Not } \\
\text { effective }\end{array}$ \\
\hline
\end{tabular}

Source: Data Processed, 2018

This AUPL is compared to the previously determined DUPL of 5\%. If:

a. AUPL> DUPL, the internal control is "Not Effective". It is said to be ineffective because the percentage error or deviation rate (AUPL) exceeds the predetermined deviation limit (DUPL) of $5 \%$.

b. AUPL = DUPL, the internal control is "Effective". It is said to be effective because the percentage error or deviation rate (AUPL) does not exceed the predetermined deviation limit (DUPL) of $5 \%$.

c. AUPL <DUPL, the internal control is "Effective". It is said to be effective because the percentage error or deviation rate (AUPL) does not exceed the predetermined deviation limit (DUPL) of $5 \%$.

According to table 3, the credit control system for Community Banks in Tulungagung is not effective. It's shown by the AUPL value that exceeds the DUPL. The effectiveness test with quantitative analysis supports previous qualitative analysis. Deviations that occur are:

1. The significant amounts of credit approval documents un-authorized, 
2. Many incomplete supporting documents for credit approval, and

3. Less verification of the truth of the transaction and the correctness of the calculation of the credit ceiling.

These three irregularities are triggering the ineffectiveness of the internal control system for the Community Banks credit system in Tulungagung. The finding in this study shows that an ineffective internal control system supports previous research (Onumah et al., 2012). According to (Onumah et al., 2012) an ineffective internal control will occur if in the organization/company exist a control deficiency, which could be described as either a significant deficiency or material weakness. According to the PCAOB Auditing Standard No. 5 (Onumah et al., 2012) explained control deficiency exists when the design or operation of a control does not allow management or employees, in the normal course of performing their assigned functions, to prevent or detect misstatements on a timely basis. Furthermore, (Onumah et al., 2012) explained that a deficiency in operation exists when a properly designed control does not operate as designed, or when the person performing the control does not possess the necessary authority or qualifications to perform the control effectively.

\section{Conclusion and Suggestion}

\section{Conclusion}

Based on the results of research and data analysis, it can be concluded that:

1. Internal control of the credit system at Community Banks in Tulungagung is effective from qualitative analysis. Qualitative analysis is based on the Professional Standards of Public Accountants (SPAP) AS Section 319 concerning Consideration of Internal Control in Audit of Financial Statements.

2. Internal control of the credit system at Community Banks in Tulungagung is not effective from quantitative reviews. Quantitative analysis uses Fixed Sample Size Attribute Sampling. This review is specific to the following attributes:

a. The significant amounts of credit approval documents un-authorized,

b. Many incomplete supporting documents for credit approval, and

c. Less verification of the truth of the transaction and the correctness of the calculation of the credit ceiling.

The result of this study also confirm previous research by (Jayanti Gagola, Ventje Ilat, 2015) which shows empirical evidence although internal control is effective, it still needs to maintain the stability of internal control mechanism. This study combining two research methods, qualitative and quantitative methods (mixed method) used to confirm previous research evidence, even though internal control in qualitative aspects is effective, it still needs to develop the research methods into deeper and more detail analysis.

\section{Suggestions}

The results of the research and discussion in the previous chapter prove that there are weaknesses in internal control of the credit system at Community Banks in Tulungagung. Its provide suggestions that could be considered by Community Banks in Tulungagung. The suggestions are as follows: 
1. Community Banks management in Tulungagung must be more thorough in checking credit approval documents in the case of authorization. The authorization is very important because authorization is a determinant of response. Documents affixed with authorization will provide information regarding who is responsible for the information in the document.

2. Community Banks management in Tulungagung must be more thorough in checking the completeness of supporting documents. Complete supporting documents will help the credit analysis process so that the determination of the credit ceiling is based on complete and accurate information.

3. Community Banks management in Tulungagung should conduct a verification test of the correctness of credit ceiling calculation. The truth and accuracy of the credit ceiling calculation will save the company's assets from things that are not useful, so customers get credit according to their portion and minimize NPL.

This study includes qualitative and quantitative analysis on internal control of the Community Bank's credit system in Tulungagung, but this research is only based on data from two Community Banks in Tulungagung. The next research can expand the scope of the study, for example adding the object of study. Besides, the next researcher can also conduct similar research on banking institutions other than Community Banks.

\section{Research Limitations}

The limitation of this study is that this study was only conducted in two Community Banks in Tulungagung. This is because there are only two Community Banks from fifteen Community Banks in Tulungagung that are willing to be used as a research object.

\section{Acknowledgement}

This research was supported by the Ministry of Research, Technology, and Higher Education (Kemenristekdikti).We thank our colleagues from Polytechnic of Kediri (Politeknik Kediri) which provide insight and expertise that greatly helped the process of this research until it's done. This research has been our laboratories for working out ideas and sharing our experiences as a researcher. In addition, we would like to thank our research assistants who greatly assisted this research. We also couldn't produce this research without our family support. We would also like to show our gratitude to all of the respondents for sharing their information about internal control.

\section{References}

1) Akwaa-Sekyi, E. K., \& Gené, J. M. (2017). Internal controls and credit risk relationship among banks in Europe. Intangible Capital, 13(1), 25-50. https://doi.org/10.3926/ic.911

2) Beasly, A. E. (2012). Auditing and Assurance Services and Integrated Approaches. (S. Wall, Ed.) (14th ed.). London: Pearson.

3) Cahyani, B. E. P. (2016). The Effectiveness Analysis of Credit System Internal Control (Case Study at PD BPR Bank Sleman), 1-149.

4) Creswell, J. (2009). Research Design. Journal of Chemical Information and Modeling, 53(9), 16891699. https://doi.org/10.1017/CBO9781107415324.004 
5) Creswell, J. W. (2014). Research Design Qualitative, Quantitative, and Mixed Methods Approach (4th Edition). (J. Young, Ed.) (4th ed.). Nebraska: SAGE publication. Retrieved from https://www.researchgate.net/file

6) IAPI. (2011). Pertimbangan atas Pengendalian Intern dalam Audit Laporan Keuangan. SA Seksi 319, (PSA 69), 1-30.

7) Jayanti Gagola, Ventje Ilat, D. A. (2015). the Analysis of Internal Control System of Credit At Pt Bank Sulut Tbk Central Office Manado. Jurnal EMBA, 3(2), 406-416.

8) Mulyadi. (2015). Sistem Akuntansi. (E. S. Suharsi, Ed.), Computers \& Education (4th ed.). Jakarta: Salemba Empat. https://doi.org/10.1017/CBO9781107415324.004

9) Narotama, Ch; Radianto, W. E. . (2004). Sistem Pengendalian Internal Dalam Organisasi BPR. Yogyakarta: Adicita.

10) Onumah, J. M., Kuipo, R., \& Obeng, V. A. (2012). Effectiveness of internal control systems of listed firms in Ghana. Research in Accounting in Emerging Economies (Vol. 12). Emerald Group Publishing Ltd. https://doi.org/10.1108/S1479-3563(2012)000012A006

11) Sekaran. (2003). Research methods for business (4th edition). New York, USA: John Wiley \& Sons (Vol. 65). https://doi.org/10.1017/CBO9781107415324.004

12) Sugiyono. (2017). Metode Penelitian Pendidikan Pendekatan Kuantitatif, Kualitatif dan R\&D. Bandung: Alfabeta. 